Short Communication

\title{
Voltage Reversal in Series-connected Three 1.5V AAA Alkaline Batteries
}

\author{
Ovidiu S. Stoican
}

INFLPR, Atomistilor Street, 409, 077125, Magurele, Romania

E-mail: stoican@infim.ro

doi: $10.20964 / 2019.01 .65$

Received: 13 June 2018 / Accepted: 8 November 2018 / Published: 30 November 2018

Discharge curves for three 1.5V AAA alkaline batteries, series-connected, were completed. The voltage across each battery as a function of time has been directly measured. For this purpose a specific measuring system has been built. Periodically, by means of a switches block, consisting of reed relays pairs, terminals of each battery are successively connected to the floating inputs of an analog-to-digital converter. The whole measurement process runs continuously, automatically, without human or computer assistance. By using the described system, batteries unbalance and reversal voltage effect occurring in over-discharge conditions have been noticed.

Keywords: alkaline battery, electrochemical battery, batteries unbalance, voltage reversal, forced discharge

\section{$\underline{\text { FULL TEXT }}$}

(C) 2019 The Authors. Published by ESG (www.electrochemsci.org). This article is an open access article distributed under the terms and conditions of the Creative Commons Attribution license (http://creativecommons.org/licenses/by/4.0/). 